\title{
Access to Justice for Children: Towards a Specific Research and Implementation Agenda
}

\author{
Ton Liefaard \\ UNICEF Chair in Children's Rights at Leiden University, Leiden Law School, \\ The Netherlands \\ t.liefaard@law.leidenuniv.nl
}

\begin{abstract}
Although the UN Convention on the Rights of the Child recognises procedural rights of the child in addition to substantive rights, it is rather silent on the fundamental right to an effective remedy. The concept of access to justice for children has nevertheless emerged in the past decades and manifested itself firmly in the international human rights and sustainable development agendas. Access to justice is grounded in the right of the child to seek remedies in case of (alleged) rights violations. It implies legal empowerment of children and access to justice mechanisms and remedies that are child-sensitive. So far, access to justice, with a specific focus on children, lacks careful consideration, conceptualisation and contextualisation in academic research and writing. This contribution explores the meaning of access to justice for children, as a right and procedural concept, and paves the way for the development of a more specific research and implementation agenda.
\end{abstract}

\section{Keywords}

UN Convention on the Rights of the Child - access to justice - right to an effective remedy - child-friendly justice - child-sensitive proceedings - legal empowerment right to legal or other appropriate assistance 


\subsection{Emergence of Access to Justice for Children}

The legal position of children under international human rights law changed with the adoption of the United Nations Convention on the Rights of the Child (CRC, UN General Assembly, 20 November 1989, A/REs/44/25) in 1989 and its entry into force one year later. Under the $\mathrm{CRC}$, the child is explicitly recognised as a human rights bearer, a legal subject entitled to all human rights and fundamental freedoms laid down in the CRC and related international human rights instruments and jurisprudence. With the adoption of the CRC in 1989 and its almost universal ratification, the international community agreed to move away from the child being perceived merely as a vulnerable and dependent human being in need of special care and assistance, and accepted that a child is, in the first place, a rights holder like any other human being. Hence, the CRC can be regarded as a game changer, at least from an international human rights perspective. And it has proven to be a catalyst for law and policy reform, litigation and advocacy, at the domestic and regional level, in the past quarter of a century (Arts, 2014; Liefaard and Sloth-Nielsen, 2017; Liefaard and Doek, 2015; Kilkelly and Liefaard, 2019).

Although the $\mathrm{CRC}$ recognises procedural rights of the child in addition to substantive rights, it is rather silent on the fundamental right to an effective remedy (art. 8, UDHR; cf. e.g. art. 2(3), ICCPR). The concept of access to justice for children has nevertheless emerged in the past decades and manifested itself firmly in the international human rights and sustainable development agendas. Access to justice is grounded in the fundamental right to an effective remedy and revolves around the right of children to seek remedies in case of (alleged) rights violations. And it concentrates on the legal empowerment of children thereto. The concept of access to justice for children can count on an increasing amount of attention, particularly within international institutions and intergovernmental organisations, such as the Human Rights Council, the Office of the High Commissioner for Human Rights (UN High Commissioner, 2013), special procedures mandate holders, UN organisations, such as UNDP and UNICEF, and international civil society organisations or networks, such as CRIN, ECPAT International, Defence for Children International and the African Child Policy Forum (CRIN, 2016, ECPAT International, 2017, Van Keirsbilck and Tomasi, 2017 and ACPF, 2018).

This development has been supported and to a certain extent stimulated by the growing body of jurisprudence of national and regional judicial and administrative bodies recognising children's legal standing (with or without representation by parents or other representatives, such as a guardian ad litem) 
and offering remedies for rights violations in a wide variety of ways (Liefaard and Doek, 2015; UNICEF, 2013). The growing acceptance that access to justice matters to children has furthermore been pushed by the interest in the position of (child) victims at the international and regional, particularly European, level, resulting in specific and detailed standards. ${ }^{1}$ In addition, the adoption of the third Optional Protocol to the CRC on individual communications (Third Optional Protocol) can be seen as a recognition of the child's right to access to justice. ${ }^{2}$ One could also point to the growing attention for responsibilities of non-state actors, including businesses, which builds on the acceptance of the notion that the availability of effective remedies matters also where the accountability of non-state actors for the protection of children's rights is concerned (CRC Committee, 2013a; UNICEF et al., 2010). And last but not least, access to justice has been included in the Sustainable Development Goals (sDGs). Target 16.3 of the sDGs provides that 'the rule of law' should be promoted at the national and international levels and that 'equal access to justice for all' (i.e. adults and children alike) should be ensured.

\subsection{Focus and Outline}

Despite the growing attention within the international and regional communities, access to justice has neither been carefully conceptualised, nor contextualised, in relation to children. Many fundamental and practical questions still need to be addressed. This contribution explores the meaning of access to justice for children, as a right and procedural concept enabling children to seek effective remedies in case of (alleged) unlawful or arbitrary treatment. It identifies the key requirements that ought to be considered when establishing such remedies for children, while taking into account barriers children are confronted with.

This contribution starts with an analysis of access to justice for children as a right and procedural safeguard, including an analysis of the right to an effective remedy as the core right underpinning children's access to justice (para. 2). After identifying the main barriers children encounter concerning access to justice in paragraph 3 , this contribution zooms in on two core requirements

1 See, e.g., UN Economic and Social Council, Guidelines on Justice in Matters involving Child Victims and Witnesses of Crime, 22 July 2005, E/RES/2005/20; European Parliament and the Council of the European Union, Minimum standards on the rights, support and protection of victims of crime, 25 October 2012, EU Directive 2012/29/EU.

2 This is not the first child-specific international communications procedure for children; that is the communications procedure under the African Charter on the Rights and Welfare of the Child; see Sloth-Nielsen, 2015 . 
for access to justice for children: (1) legal empowerment of children, which relates to children's legal status under international law and includes matters related to the legal capacity of children, legal representation and legal or other appropriate assistance (para. 4); and (2) the availability of child-friendly or child-sensitive proceedings (para. 5). In doing so, this contribution not only aims to provide a better understanding of the child-specific implications of access to justice for children, both conceptually as well as practically, it also identifies critical steps that ought to be considered by legislators and policy makers when implementing access to justice for children. This could also serve as a source of inspiration for the operationalisation of the Third Optional Protocol to the CRC, although this instrument providing children with an international complaint mechanism will not be further addressed in this contribution. This contribution closes with some concluding observations and recommendations for a research agenda (para. 6).

\section{Access to Justice for Children}

\subsection{Access to Justice and the Right to an Effective Remedy}

In his December 2013 report on access to justice for children, the UN High Commissioner for Human Rights (UN High Commissioner) defined access to justice for children as 'the ability to obtain a just and timely remedy for violations of rights as put forth in national and international norms and standards, including the [CRC]' (UN High Commissioner, 2013, para. 4 with reference to UN Common Approach to Justice for Children, UNICEF, 2008: 4). The High Commissioner observed that access to justice 'is a fundamental right in itself and an essential prerequisite for the protection and promotion of all other human rights'. This suggests that access to justice for children should be understood both as a fundamental right and as a means to safeguard the enjoyment of just and timely remedies in relation to the protection of substantive rights of the child (see also Francioni, 2007: 30 and 32-33). International human rights treaties do not explicitly refer to a right to access to justice (apart from the 2006 Convention on the Rights of Persons with Disabilities; art. 13 (1)), but they do recognize everyone's right to an effective remedy, grounded in article 8 of the Universal Declaration of Human Rights (UDHR), and states parties' obligations in this regard. According to the Human Rights Committee the right to an effective remedy as laid down in article 2(3) ICCPR requires states parties to ensure that individuals can vindicate their rights through 'accessible and effective remedies' (Human Rights Committee, 2004, para. 15). In this way access to justice serves as a procedural guarantee meant to protect substantive and 
procedural rights of individuals (Francioni, 2007, p. 32). Shelton also refers to access to justice as a means to provide (domestic) remedies, which essentially comes down to 'ensuring the possibility of an injured individual or group to bring a claim before an appropriate tribunal and have it adjudicated' (Shelton, 2015, p. 96). At the same time, it can be argued that access to justice has been acknowledged by regional human rights courts and treaty bodies as a human right in the context of domestic law and under international human rights law (Francioni, 2007, pp. 41-42), which comes with negative as well as positive obligations for states parties (Shelton, 2015, p. 96 with reference to InterAmerican Commission on Human Rights 2007). States must prevent that law or practice hinder individuals to seek remedies, but they should also provide effective remedies and enable individuals to access these.

This is of equal value to children, although it should be acknowledged that the right of a child to an effective remedy may not seem self-evident at first sight. In addition, a child faces specific and sometimes different challenges when it comes to access to justice (the latter will be addressed further below in para. 3). As mentioned in the introduction, the CRC does not explicitly refer to the right to an effective remedy (O'Donnell, 2009, pp. 2-3). However, according to the UN Committee on the Rights of the Child (CRC Committee) it is 'implicit in the [CRC] and consistently referred to in the other [...] major international human rights treaties' and in order for '[children's] rights to have meaning, effective remedies must be available to redress violations' (CRC Committee, 2003, para. 24; art. 41 CRC; UN High Commissioner, 2013, para. 11). In relation to this, the CRC Committee observes that ' $[\mathrm{i}] \mathrm{t}$ is essential that domestic law sets out entitlements in sufficient detail to enable remedies for non-compliance to be effective' (emphasis added) (CRC Committee, 2003, para. 25). Despite the absence of an explicit instruction towards states parties to safeguard the right of the child to an effective remedy, the CRC does contain provisions on rights to remedy or to challenge specific decisions affecting the child. For example, a child deprived of his ${ }^{3}$ liberty has the right to challenge the legality of the deprivation of liberty before a judicial or other competent, independent or impartial body (art. 37(d) CRC). Article 40(2)(b)(v) CRC additionally grants every child considered to have infringed the penal law the right to appeal before 'a higher competent, independent and impartial authority or judicial body according to law' and article 25 CRC provides the right to a periodic review to a child who has been placed out of home by the competent authorities for the purposes of care, protection or treatment of his physical or mental health.

3 For practical reasons, this contribution refers to the child in the masculine form. All that is said about 'him', however, applies to 'her' as well, unless stated otherwise. 
Last but certainly not least, the Third Optional Protocol grants a child the right to lodge individual communications at the international level. It is too early to say how the CRC Committee, competent to receive individual communications under the Third Optional Protocol, approaches the issue of effective remedies and to what extent it will make the child's right to an effective remedy explicit in its decisions. It can be assumed, however, that the adoption of this optional protocol has confirmed that a child has the right to an effective remedy, falling within the concept of access to justice.

In conclusion: there is a clear relation between access to justice and the right to an effective remedy. The definition of access to justice revolves around the ability to obtain remedies. This implies that the child should have access to justice in order to exercise his right to an effective remedy.

\subsection{Scope of Access to Justice}

According to the UN High Commissioner access to justice for children 'applies to civil, administrative and criminal spheres of national jurisdictions, including customary and religious justice mechanisms, international jurisdictions, as well as alternative and restorative dispute resolutions' (UN High Commissioner, 2013, para. 4). It covers 'all relevant judicial proceedings, affecting children without limitation, including children alleged as, accused of, or recognised as having infringed the penal law, victims and witnesses [of crimes] or children into contact with the justice system for other reasons, such as regarding their care, custody or protection' (ibid.). This points at a broad notion of access to justice, which recognises that children engage with justice proceedings in many different ways: as victims, offenders, interested party etcetera. It also implies that access to justice goes beyond safeguarding access to judicial tribunals (Francioni, 2007: 3-4; Shelton, 2015: 96 and 10off; CRC Committee, 2003, para. 24). This resonates with the approach under general human rights treaties. Article 2(3) ICCPR provides that states parties must 'ensure that any person claiming ... a remedy shall have his right ... determined by competent, judicial, administrative and legislative authorities, or by any other competent authority provided for by the legal system of the State, and to develop the possibilities of judicial remedy'. The Human Rights Committee underscores that ' $[a]$ dministrative mechanisms are particularly required to give effect to the general obligation to investigate allegations of violations promptly, thoroughly and effectively through independent and impartial bodies' (Human Rights Committee, 2004, para. 15). One can think, among other things, of the role of National Human Rights Institutions (NHRIs), such as ombudspersons, that can play a preventive and investigative role. NHRIs can also offer (non-judicial) remedies for human rights violations, for example through 
complaints procedures. As far as judicial remedies are concerned, international instruments are somewhat confusing. The wording of article 2(3)(c), ICCPR indicates that the possibility of a judicial remedy must be developed as a form of appeal, while article 25, ACHR provides the right to an effective judicial remedy, under the ACHR and the national constitution (De Schutter, 2010: 733). Under the ECHR, however, the right to an effective remedy does not always require access to a judicial remedy, 'since other remedies may present the required effectiveness' (ibid:: 735 with reference to ECtHR, 5 February 2002, appl. no. 51564/99 (Čonka v. Belgium), para. 75; see also FRA and Council of Europe, 2015). According to Shelton, administrative remedies can be adequate if they are 'accessible, affordable, timely or prompt, effective, legitimate, predictable, compatible with rights, and transparent'; remedies must also be 'equitable' (Shelton, 2015: 100). At the same time, the significance of judicial remedies (direct or via appeal) is beyond any doubt (Shelton, 2015: 99-100). The type of remedy required depends on the nature and gravity of the allegation (Shelton, 2015: 94) and this is also related to the remedy's function (see, e.g., Liefaard, 2017a). In conclusion, access to justice can have different forms and the right to an effective remedy can be secured through access to judicial procedures but also through administrative and other formal or informal procedures (see, e.g., ACPF, 2018).

\subsection{Access to Justice - A Procedural and Substantive Concept}

The report of the UN High Commissioner reflects the common approach towards access to justice for children at the international level, emerging in the past two decades, which is primarily about the right to legal action against rights violations, but which 'more broadly encompasses equitable and just remedies' (UNICEF, 2015: 18). In this approach, access to justice is considered an 'integral component of any good rule of law framework' as well as 'a prerequisite for sustainable development, the eradication of poverty, and greater equality'(ibid.); an approach which can count on broad support internationally. UNICEF, for example, has defined access to justice as 'the right to obtain a fair, timely and effective remedy for violations of rights, as put forth in national and international norms and standards, through adapted processes that protect children's dignity and promote their development' (ibid: 3 ; cf. UNICEF, 2008). UNDP has provided similar definitions, which have also informed the ones mentioned above, and has stated that access to justice is 'much more than improving an individual's access to courts, or guaranteeing legal representation' (UNDP, 2005: 5). According to the UNDP, '[i]t must be defined in terms of ensuring that legal and judicial outcomes are just and equitable' (UNDP, 2004: 6; UN Approach to Justice for Children, 2008: 4; UNICEF, 2015: 18; cf. Bedner 
and Vel, 2010). Access to justice, thus, is considered by international organisations as a procedural concept as well as a substantive one, which finds support in international law (see, e.g., art. 39, CRC) and legal doctrine on the matter (Shelton, 2015: 16-17; Francioni, 2007).

This relates to the outcome of the proceedings and the reparation, relief or compensation offered to the individual child, that is: the effectiveness of the remedies sought (Shelton, 2015: 16). According to art. 2(3), ICCPR states parties are under the obligation to ensure that 'the competent authorities shall enforce ... remedies when granted'. The effectiveness of remedies essentially comes down to the competence of the relevant authorities to take a decision on the merits of the complaints and to provide adequate redress for any violation found (De Schutter, 2010: 737; Council of Europe Recommendation Rec (2004) 6 of the Committee of Ministers to Member States on the improvement of domestic remedies). The state is subsequently held to make reparations or offer redress, without which 'the obligation to provide an effective remedy, which is central to the efficacy of article 2, paragraph 3, is not discharged' (Human Rights Committee, 2004: para. 16). The Human Rights Committee adds that, where appropriate, reparation can involve compensation as well as 'restitution, rehabilitation and measures of satisfaction, such as public apologies, public memorials, guarantees of non-repetition and changes in relevant laws and practices' (ibid.). In this regard, the Inter-American Court on Human Rights has taken a rather strong position by providing that 'the objective of international human rights law is ... to protect the victims and to provide for the reparation of damages' (Shelton, 2015: 1 with reference to Inter-American Court of Human Rights, Velasquez Rodriguez v. Honduras (1988) Series C, 28, ILM 291: para. 134; Feria Tinta, 2015). In doing so '[i]t places reparations at the centre of the entire human rights project' (Shelton, 2015: 1). The CRC Committee has provided that children whose rights have indeed been violated should receive 'appropriate reparation, including compensation, and, where needed, measures to promote physical and psychological recovery, rehabilitation and reintegration, as required by article 39 [CRC]' (CRC Committee, 2003: para. 24). This makes clear that remedies with regard to children should move beyond financial compensation and should take into account the rights of children in a holistic manner. Compensation could, for example, be used to support the child's development and education, requiring a pedagogical orientation, and should take into account the child's views and wishes (art. 39 jo., arts. 6 and 12 CRC, respectively). Where the CRC Committee does not provide much further guidance (and it is too early to tell how the CRC Committee engages with remedies under the Third Optional Protocol), the Inter-American Court of Human Rights has proven to be rather creative by ordering the establishment of 
investment and trust funds for victims as well as public apologies and acknowledgments in which, for example, public places such as streets and squares are named in honour of the children concerned (Feria Tinta, 2015).

\section{Barriers for Children Accessing Justice and Related Challenges}

The CRC Committee has observed that '[c]hildren's special and dependent status creates real difficulties for them in pursuing remedies for breaches of their rights' (CRC Committee, 2003: para. 24). Therefore, states 'need to give particular attention to ensuring that there are effective, child-sensitive procedures available to children and their representatives' (ibid.). Such procedures 'should include the provision of child-friendly information, advice, advocacy, including support for self-advocacy (Fridriksdottir, 2015: 70-71), and access to independent complaints procedures and to the courts with necessary legal and other assistance' (CRC Committee, 2003: para. 24). Indeed, children face many barriers when it comes to remedies and this affects their effectiveness (UN High Commissioner, 2013: paras. 13ff; UNICE F 2015: 9-13 and 66ff.). ${ }^{4}$ Some of these barriers are general and affect children in the same way as they affect adults. Poverty and economic status, for example, can mean that an individual cannot afford a lawyer. Other general barriers include procedural costs, location of courts, physical access, which for instance has relevance for individuals with disabilities, and legal barriers, such as statutory limitations and the denial of legal standing (Shelton, 2015: 98-99; UN High Commissioner, 2013: para. 16). These general barriers can be real for adults and children alike, but the implications may be different and require different action. Children may face particular legal barriers, because they are denied legal capacity, legal standing or a lawyer in their own name, which can be especially problematic in case of a conflict of interest between the child and his parents or legal guardian (CRIN, 2016). On top of this, children face particular barriers when accessing justice posing specific challenges. Such barriers relate to the complexity of justice systems, which makes it rather difficult for children to get access and to participate effectively. Children may also be unaware of their rights and lack essential information, for example on how to acquire (legal) assistance and on what to expect from it. Moreover, justice mechanisms may not be adjusted to children; they may neither be child-specific nor child-friendly. They may even be discriminatory towards children or specific groups of children. Justice

4 Barriers must be distinguished from lawful limitations on the right to access justice; see e.g. Francioni, 2007: $38 \mathrm{ff}$. 
systems can also be unsafe for children (intimidating or stigmatising) and children may not have the trust and confidence that their input will be taken seriously or addressed in a fair manner (UN High Commissioner, 2013: para. 15). Furthermore, cultural and social norms can stand in the way of accepting that children have a right to access justice (or have rights at all) and should be able claim redress (ibid:; UNICEF, 2015: 8off.). This can also explain the (continued) existence of legal and practical barriers and the lack of incentives to change that. Finally, certain groups of children face particular difficulties in accessing justice. Children deprived of their liberty can be considered one of them (hence, the inclusion of art. 37(d) in the CRC; see also UN High Commissioner, 2013), but other groups include children with disabilities (Carter, 2016), refugee or migrant children and children in the justice system, either as (alleged) offenders or as victims and/or witnesses (UN High Commissioner, 2013, para. 17).

To overcome challenges and barriers, the UN High Commissioner has emphasised, like the CRC Committee, the significance of child-sensitive procedures and the legal empowerment of 'all' children, which encompasses access to 'legal and other services, child rights education, counselling or advice, and support from knowledgeable adults' (ibid.: para. 5). Hence, this contribution will continue by addressing these two main categories of requirements for access to justice, which are particularly relevant for children or have specific implications for children.

\section{Legal Empowerment of Children}

\subsection{Introduction}

The 'legal empowerment of all children' (UN High Commissioner, 2013: para. 5) relates to the legal capacity of children and the role of parents or others in legally representing their child. It also concerns the issue of legal or other appropriate assistance. The CRC provides some guidance on the legal capacity of children and the position of parents, but it does not, for example, include a clear entitlement to legal or other assistance, at least not outside the context of the criminal justice system (see art. 40 (2)(b)(ii) and (iii) CRC, which deals exclusively with children in conflict with the law). This paragraph zooms successively in on the legal capacity of children to take action, legal representation and legal or other appropriate assistance.

Before doing so, it is important to underscore that the justiciability of children's rights will not be addressed in this contribution (see CRC Committee, 2003: para. 25 and CRC Committee, 2013b: paras. 119-120; see also, e.g., Nolan, 2011). It should also be acknowledged that legal empowerment is related to a 
number of other issues that require attention, but will not be addressed in this contribution either. These include birth registration (see art. 7, CRC) and statutory limitations (see further UN High Commissioner, 2013).

\subsection{Legal Capacity of Children to Take Legal Action ${ }^{5}$}

One of the legal barriers for accessing justice concerns the legal capacity (or better: incapacity) of a child to take legal action. In many domestic jurisdictions, the starting point is that a child, as a minor, does not have the legal capacity to commence legal (judicial) or administrative procedures on his own behalf or to formally approach a court of law to vindicate his rights, independently from his parents or legal guardian (UN High Commissioner, 2013: para. 37; CRIN, 2016: 17; O'Donnell, 2009: 2 and 3; Fridriksdottir, 2015: 6o-61). A child's legal representative could start such a procedure on behalf of their child or assist a child in doing so. The CRC is not explicit on this matter. It merely clarifies the legal position of children in general. The CRC provides that parents have the primary responsibility for the upbringing and development of their child and that the child's best interests will be their basic concern (art. 18(1), CRC). This means that parents have a substantial amount of discretion to determine what they believe is in their child's best interests. With regard to legal action, this essentially boils down to the question of whether taking legal action on behalf of the child in the parents' view serves the child's best interests. If so, the parents can count on support for their decision on the basis of article 18, CRC. This decision-making authority does not lie exclusively with the parents, however. The right to access justice can be regarded as a right of the child and, although article 5 , CRC provides that parents are the ones to guide their child in the exercise of his rights, this must be done in a manner consistent with the child's evolving capacities. This implies that at a certain point, depending on a child's age and maturity, the child should be allowed to exercise his own rights (alone or together with his parents or guardian); as a minimum, he ought to have a say in the decision making affecting his right to access justice (art. 12, CRC and CRC Committee, 2009: paras. 9off). It thus seems more a matter of when a child can exercise his right independently from his legal representatives, rather than if he should be entitled to do so. In light of this, the exclusion of legal capacity for all children (as a category) without giving due weight to the child's evolving capacities is questionable in light of art. 5 of the CRC. This position finds support

5 The focus in this paragraph will be on access to justice at the domestic level. For more on the international level, see e.g., Skelton, 2018. 
in the fact that many jurisdictions have exceptions to the rule that children do not have legal capacity (Kennan and Kilkelly, 2015). ${ }^{6}$

Some jurisdictions have acknowledged children's legal capacity to initiate judicial or administrative proceedings. The South African Children's Act, for example, grants '[e]very child' the right to initiate judicial proceedings (Section 14 of the Children's Act; Boezaart, 2009: 22-23 (with reference to the common law starting point that an infant has no capacity to litigate: 22) and 34-35). Skelton observes that, 'it is ... evident that under South African law children can act in their own name and litigate all the way to the Constitutional Court' (Skelton, 2015: 16). In other jurisdictions children are entitled to do so when they are of a certain age or in individual cases when a child is considered to have the capacity to understand legal proceedings (UN High Commissioner, 2013: para. 37 with reference to examples from the Russian Federation; see also Joint report, 2012: 12 and Fortin, 2009: 114). There are also many examples of legal systems that provide for low threshold forms of access to justice as alternatives for judicial or administrative mechanisms. Examples include complaints mechanisms in detention centres or custodial institutions or at national human rights institutions or (children's) ombudspersons (Liefaard, 2017a and Joint report, 2012: 11-12; see also Rees, 2010 and CRC Committee, 2002). Within many criminal justice systems, the minimum age of criminal responsibility basically is defined as the age at which a child is considered capable of making procedural decisions including, for example, the right to appeal a court's decision (Liefaard, 2015).

In general, legal representation by parents or others does not need negatively to affect the child's right to access justice. However, the dependence of children on their legal representatives can become problematic for different reasons, two of which will be mentioned here. First, it may imply that children are not involved in the procedures, which negatively affects their right to be heard and to participate. Skelton (2015: 16) refers to the South African Constitutional Court case MEc for Education, KwaZulu-Natal and Others v. Pillay (5 October 2007 (no. СCT 51/o6)) which was brought by the mother of a teenage girl, who claimed that her daughter had been discriminated against on the basis of religion and in which the court observed that it would have liked to hear from the girl herself, particularly as the case concerned her religion or culture. Justice Langa observed (para. $5^{6}$ ):

It is always desirable, and may sometimes be vital, to hear from the person whose religion or culture is at issue. That is often no less true when

6 Fortin notes that in England and Wales it is rather unusual for children to take legal action on their own; Fortin, 2009: 234. 
the belief in question is that of a child. Legal matters involving children often exclude the children and the matter is left to adults to argue and decide on their behalf.

Indeed, this is why article 12, CRC provides that the child has the right to be heard, which can also be regarded essential in light of the reality that children are not necessarily involved in litigation affecting them and their rights (O'Donnell, 2009: 3).

A second problem occurs in the situation of a conflict of interests or in case the parents are the ones who have infringed upon the rights and freedoms of their child. ${ }^{7}$ Many jurisdictions provide for the possibility to appoint an alternative or ad hoc representative in such situations, for example a guardian or curator ad litem (ibid.; Boezaart, 2009: 34-35; see also Parkes, 2013: 100-103 and Fortin, 2009: 234ff and 256ff). Sometimes children can also lodge a request for such an appointment and have the right to appeal the court's refusal to do so (see e.g.: Hoge Raad (The Netherlands Supreme Court), 29 May 2015, ECLI:NL:HR:2015:1409). In general, 'ad hoc legal guardians' (UN High Commissioner, 2013: para. 38$)^{8}$ are appointed to represent the child's interests in a certain case, which means that they assess what is in the best interests of the child and inform the court accordingly. In addition, they provide the child with information on the case and the expected course of the proceedings. This might overlap with the role of a lawyer (see below), but also points at the potential conflict of roles. An assessment of the child's best interests is not the same as legal representation. The latter requires a broader approach and includes representation of the child's views, not only on the matter but also on the procedural steps that can be taken.

\subsection{Legal or Other Appropriate Assistance}

4.3.1 A Child's Right to Legal or Other Appropriate Assistance?

Another element of the legal empowerment of children concerns the right to legal or other appropriate assistance. The CRC provides that a child has a right to legal or other appropriate assistance when he is subjected to criminal justice proceedings (art. 4o(2)(b)(ii) and (iii) CRC). It also stipulates that each child,

7 This includes the situation in which parents do not act on behalf of the child because they do not want to access justice on behalf of their child.

8 The UN High Commissioner acknowledges that in specific cases concerning systematic, grave or widespread violations of children's rights, children could benefit from assistance by csos, NHRIs, legal clinics etcetera; UN High Commissioner, 2013: para. 39. See also Skelton (2015: 16-17) pointing at the active role of child rights organisations, which could have legal standing themselves, even if they do not litigate on behalf of children, or could support a child or children in indirect ways (e.g. through amicus briefs). 
who is deprived of his liberty, is entitled to 'legal and other appropriate assistance' (emphasis added), which has implications for all forms of deprivation of liberty, within and outside the context of criminal justice (art. 37(d), CRC). However, the CRC does not provide a child with a general right to legal assistance (i.e. outside the context of the criminal justice systems or deprivation of liberty), let alone a right to assistance that is free of charge (UN High Commissioner, 2013, para. 43). The latter relates to the right to legal aid, which aims to ensure 'effective access to justice for those who have insufficient financial resources to cover the costs of court cases, such as court fees or costs of legal representation' (FRA and Council of Europe, 2016: 58). As mentioned earlier, costs related to accessing justice turn out to be particularly problematic for children. This calls for a legal aid scheme supporting children, and particularly children facing financial barriers due to poverty or their specific status as a migrant or refugee child or street child, among others (UN High Commissioner 2013: para. 17). ${ }^{9}$ At the national level, free legal aid for children outside the criminal justice system is guaranteed only in specific matters and parents are usually considered to be the ones who should represent their child. This finds support in the case law of the European Court of Human Rights, on the basis of which legal aid is in general subject to a financial means and merits test, even though it is acknowledged that legal aid is particularly relevant for the right to access justice, which should be 'practical and effective' (FRA and Council of Europe, 2016: $58 \mathrm{ff})$. States have the discretion to assess whether the interests of justice require providing legal aid, while taking into account: the importance of the case to the individual; the complexity of the case; and the individual's capacity to represent himself (ibid:: 58). In the context of criminal justice, the European Court's case law has provided more clarity of the implications of the 'financial means' and 'interests of justice' test (ibid.: 66). It also specifically recognised that children have a particular interest in receiving legal assistance, an interest that is without any doubt and imposes direct obligations upon states in case of police interrogations and deprivation of liberty (FRA and Council of Europe, 2015: 197-205; ECtHR (GC), 27 November 2008, appl. no. 36391/o, (Salduz v. Turkey); ECtHR, 11 December 2008, appl. no. 4268/04 (Panovits v. Cyprus); see also European Parliament and the Council of the European Union, Procedural safeguards for children who are suspects or accused persons in criminal proceedings, 11 May 2016, Directive (EU) 2016/80o).

9 See also United Nations Basic Principles on the Role of Lawyers, 7 September 1990 (UN Basic Principles on the Role of Lawyers), providing that states should 'ensure the provision of sufficient funding and other resources for legal services to the poor and, as necessary, to other disadvantaged persons', paras. 2-3. 
This having been said, the right to legal or other appropriate assistance is perceived as one of the most crucial prerequisites for children accessing justice and an essential element of fair and child-friendly treatment (see also para. 5; ECtHR, 20 January 2009, appl. no. 70337/01, (Güveç v. Turkey), para. 31; see also ECtHR, 15 June 2004, appl. no. 60958/oo, (S.C. v. United Kingdom), in which the ECtHR considers that the shortcomings, including in particular the lack of legal assistance for most of the proceedings, worsened the consequences of the applicant's inability to participate effectively in his trial and infringed his right to due process). According to the UN High Commissioner, 'children will largely be unable to access complex legal systems that are generally designed for adults' (UN High Commissioner 2013: para. 40), without assistance legal and other service ... counselling or advice, and support from knowledgeable adults' (UN High Commissioner, 2013: para. 5). In other words, children are strongly in need of legal or other appropriate assistance in order to enjoy their right to access justice and such assistance should be free of charge (or subsidised) and effective. Getting access to free legal assistance is easier said than done. The availability of legal aid also depends on availability (financial and human resources) and calls for creative solutions with regard to legal assistance. In addition, one should differentiate between the legal matters at stake (i.e. the higher the child's interest, the more there is a need for assistance) and the fora to which the child could go (i.e. the more complex a forum is, the more there is a need for assistance of a legal expert) (see, e.g., Skelton (2015:17) who points at the rule under South African case law that applicants in constitutional litigation are not at risk of a costs order against them, which means that children can access justice in constitutional matters, including challenges under the Bill of Rights).

\subsubsection{Role of the Legal or Other Appropriate Assistant}

The appropriateness of (legal) assistance is related to the function of the assistance and the expectations one has or can have in this regard. In relation to access to justice, the legal empowerment of children, which includes information on their rights and means to exercise these rights, assumes that children can particularly benefit from legal assistance. However, other forms of assistance can also be relevant and will be focused more on the protection of the child's well-being and his best interests; for example, psychological assistance for child victims in order to avoid secondary victimisation. Other forms of assistance can also offer more proactive support to children who wish to access justice. This could, for example, prevent the child from going through formal legal proceedings or could assist him in the preparation of his case. International standards proclaim that legal or other assistants must be properly 
educated and trained, but they are less clear on professional standards, which is particularly relevant in relation to the potentially conflicting roles of legal or other assistants in relation to children. As far as the role of legal assistants is concerned, there may be ambiguity in the objectives of the legal assistance, which is similar to the potentially ambiguous and potentially conflicting roles of the ad hoc legal representative (e.g. guardian ad litem) mentioned earlier (Parkes 2013: 103-104; see also, e.g., Fridriksdottir 2015: 67 with reference to Duquette and Darwall, 2012). Should a lawyer zealously assist the child in exercising his right to access justice? Or does he (also) have a responsibility in light of the child's best interests and what, for example, does this mean for the child's direction in the decision-making process concerning judicial or other proceedings he initiated (directly or indirectly)? The Council of Europe's Guidelines on child-friendly justice (Guidelines on child-friendly justice or Guidelines $)^{10}$ underscore that ' $[c]$ hildren should be considered as fully fledged clients with their own rights and lawyers representing children should bring forward the opinion of the child' (Guidelines, Part IV, D., para. 40). In practice, however, the distinction between both roles is not clear and perceived differently, and children may require different kinds of assistance, also in light of their age and maturity (Duquette and Darwall, 2012: 94; Parkes 2013: 104ff; Buss 1996; Fortin 2009).

\subsubsection{Education and Training - Professional Standards}

The UN Basic Principles on the Role of Lawyers require states, professional associations of lawyers and education institutions to ensure that lawyers have appropriate education and training, and that they are also made aware of human rights and fundamental freedoms (art. 9, UN Basic Principles on the Role of Lawyers). Particularly with regard to children, 'appropriate assistance' means appropriate according to the circumstances of the case and the needs of the child (CRC Committee, 2007b, paras. 49-50 with regard to article 4o(2)(b)(ii), CRC). In this regard the CRC Committee has addressed the responsibility of states to develop (and evaluate) training and codes of conduct for legal professionals (e.g., lawyers) on how to hear children, and ensure their interests are represented in practice (ibid:: para. 49; CRC Committee, 2009: paras. 37 and 49; CRC Committee 2003: paras. 53 and 55). The Guidelines on child-friendly justice also advocate education and (on-going) training of lawyers representing children. Training should include knowledge of children's rights and related issues, but also communication with children.

10 Council of Europe, Guidelines of the Committee of Ministers of the Council of Europe on child-friendly justice, Strasbourg, 17 November 2010. 
Apart from this, international human rights law provides no guidance on standards for appropriate legal assistance to children. At the national level, however, one comes across examples of professional standards, particularly with regard to the role of lawyers representing children. For example, the American Bar Association ( $\mathrm{ABA}$ ) has adopted standards relating to the representation of children in abuse and neglect, and custody cases American Bar Association Section of Family Law, Standards of Practice for Lawyers Representing Children in Custody Cases, August 2003 (ABA Custody Standards) and American Bar Association, Standards of Practice for Lawyers Who Represent Children in Abuse and Neglect Cases, February 1996 (ABA Abuse and Neglect Standards). Among other things, the standards require lawyers to meet with child clients, explain the proceedings in an adapted manner, participate and initiate negotiations and mediations, and represent the child throughout all stages of the judicial proceedings (Elrod, 2003; ABA Abuse and Neglect Standards, A-3, C-1; ABA Custody Standards, I-1, I-2 (1)-(9), II (E), III (A)-(H), VI (B) (1)-(12)). The ABA standards also recognise that lawyers representing children require specialised training, such as in relation to relevant legal standards, communication with children, child development, value of multi-disciplinary input, etcetera (Elrod, 2003: 118-119). The need for specialised training is also given due to the increased complexity of laws and rules applicable to children, including international and regional standards. In the past decade, different on- and off-line materials were developed to enable legal and other professionals to educate and train themselves in assisting children who wish (or need) to have access to justice. ${ }^{11}$

\subsubsection{Objective and Role of Legal Assistance}

In addition to the lack of clarity regarding the competence and specialisation of legal assistance, there can also be ambiguity in relation to the objectives of the legal assistance and the role of the lawyer. Due to children's vulnerabilities and difficulties fully to understand and effectively participate in legal proceedings, lawyers representing children often find themselves 'wearing multiple hats': acting as an attorney who represents the child client, acting as guardian ad litem, or acting in some hybrid capacity (ibid:: 106). This situation has been criticised as resulting in lack of definition of the roles and objectives of the

11 See, e.g., the TALE project, which 'provides online training and advice for legal practitioners to support their work with children'; http://www.project-tale.org (last visited 1 February 2019). Or the "Advancing the Defence Rights of Children" training programme: https:// www.fairtrials.org/legal-training?module-1-introduction-to-juvenile-justice (last visited 1 February 2019). 
legal assistance, as well as in inadequate training (ibid.). The ABA, for example, has therefore distinguished between two types of legal assistance in cases that relate to children: the child's attorney; and the child's best interests lawyer. The 2003 ABA Custody Standards explicitly exclude guardians ad litem from its scope, applying only to lawyers serving as advocates for children or their interests. It notes that the term "guardian ad litem" has become 'too muddled', comprising too many functions. The standards thus hold that lawyers representing children should be, first and foremost, lawyers, focusing on advocating and protecting the legal rights and interests of child clients (ABA Custody Standards, II (A)-(B); see also the commentary on the Standards: 2; Elrod, 2003: $115,117)$. The standards allow two alternative capacities for lawyers. First, the child's attorney, who represents the child with the same loyalty, confidentiality and competence as an adult client, and views the child as an individual with independent views (Elrod, 2003: 119). The child's attorney is bound by the child's decisions, when the child is competent to direct the lawyer and if he has done so (ABA Custody Standards, II (B) (1), IV (C); Elrod 2003: 120). Second, a best interests lawyer provides independent legal services for protecting the best interests of the child, without being bound by the child's views (ibid., II (B) (2); Elrod, 2003: 115, 121). In that regard, the standards require that the determination of the best interests of the child shall be based on gathering and weighing evidence, applying legal standards, considering the particular child's needs and development, and taking into consideration consultation with experts (ibid., v (F); Elrod, 2003: 122). In cases in which the child's attorney determines that pursing the child's expressed wishes would place the child at risk of substantial physical, financial or other harm, he may request the appointment of a best interests attorney, and continue to represent the child's position (ibid., IV (C) (3)). This enables a balance between a child's right to be heard and utilise legal assistance to further his ends, and the need to safeguard children's well-being and interests. The ABA advocates a separation of roles, focusing on the legal assistance and assistance targeted at the child's interests.

This is - of course - just one way of regulating the different "hats" legal or other appropriate assistance can wear, but it seems altogether even more relevant that a child in one or the other way is aware of what he can expect from legal or other assistance. ${ }^{12}$ This relates to proceedings, including the provision

12 See for another example, the "Guidelines for legal representative of children in civil matters", developed by the Legal Aid South Africa and the Centre for Child Law, University of Pretoria (January 2016); http://www.pulp.up.ac.za/component/edocman/guidelines-forlegal-representatives-of-children-in-civil-matters (last visited 1 February 2019). 
of information, that are friendly to children and enable them to participate effectively, and less dependently from parents and others (Coley, 2007: 70).

\section{$5 \quad$ Child-sensitive Justice Proceedings}

\subsection{Introduction}

The availability of child-sensitive procedures is the second category of requirements essential for a child's access to justice that will be addressed in this contribution. According to the UN High Commissioner, child-sensitive procedures can have different forms and include different fora, including, for example, national human rights institutions and children's ombudspersons competent to receive complaints or to respond in another way to grievances of children. One could also think of forms of alternative dispute resolution (ADR) and dispute resolution processes in customary and religious justice systems (UN High Commissioner, 2013: paras. 30-31). However, child-sensitive procedures start by acknowledging that children have a right to access justice and have legal standing if they have an interest in seeking remedies. Procedures available should always and holistically take into account the rights of the child, which among other things means that children have the right to be heard and the right not to be discriminated. The latter should be seen as an incentive for securing access for different groups of children, including children who belong to the most stigmatised groups of society, such as children belonging to minorities, street children, refugee or migrant children, children deprived of their liberty, children with disabilities and children at risk because of social welfare and/or (mental) health issues (UN High Commissioner, 2013: para. 52-53). ${ }^{13}$

The term "child-sensitive" stems from the UN Guidelines on Justice in Matters Involving Child Victims and Witnesses of Crime (Economic and Social Council Res. 2005/20, 22 July 2005 (UN Guidelines); UN High Commissioner, 2013: paras. 18ff and 21ff) and has been defined as 'an approach that [balances] a child's right to protection and that takes into account a child's individual

13 The UN High Commissioner points at the position of children with disabilities, which has not been addressed by efforts to ensure access to justice for children at special risk; see para. 53. In its various General Comments, the CRC Committee underscores the significance of access to justice for specific groups of children (e.g. indigenous children (CRC Committee, 2009a), child victims of violence (CRC Committee, 2007a and CRC Committee, 2011) or unaccompanied or separated children (CRC Committee, 2005), although it does not provide much guidance on the specific implications of access to justice for these children. 
needs and views' (art. 9(d), UN Guidelines). It revolves around recognising children's agency in seeking justice through remedies in a 'just and timely manner' (UN High Commissioner, 2013: 4) on the one hand, and protecting children's rights and interests at the same time. A related concept is the concept of childfriendly justice, which has found its way to a set of guidelines adopted by the Committee of Ministers of the Council of Europe in 2010, the Guidelines on child-friendly justice. ${ }^{14}$

The Guidelines on child-friendly justice build on international children's rights and provide detailed guidance for Council of Europe member-states on how to enable children to participate effectively before, during and after justice proceedings. They deal with 'the place and role, and the views, rights and needs of the child in judicial [and alternative] proceedings' (Guidelines, First Part, Chapter I at para. 1), and in doing so the guidelines were the first instrument to articulate the essential elements of justice systems from a children's rights perspective in a comprehensive manner (Liefaard and Kilkelly, 2019). Child-friendly justice -

refers to justice systems that guarantee the respect and the effective implementation of all children's rights at the highest attainable level, bearing in mind the principles listed [in the Guidelines] and giving due consideration to the child's level of maturity and understanding and the circumstances of the case' (Guidelines, under II.c).

As a concept, child-friendly justice is,

in particular, justice that is accessible, age appropriate, speedy, diligent, adapted to and focused on the needs and rights of the child, respecting the rights of the child including the rights to due process, to participate in and to understand the proceedings, to respect for private and family life and to integrity and dignity' (ibid.).

14 The concept of child-friendly justice is used in other parts of the world as well. For example, the International Association of Youth and Family Judges and Magistrates (AYFJM) has ratified the "Guidelines on Children in Contract with the Justice System", which were developed on the basis of the child-friendly justice guidelines and its equivalents in Africa and Latin America (2017: 6). The IAYFJM Guidelines use the term "child focused justice", which the IAYFJM deemed more appropriate in relation to the context of juvenile justice (2017:11); http://www.aimjf.org/storage/www.aimjf.org/Documentation_EN/AIMJF/ Guidelines_-_ENG_-_Ratified_17.04.26.pdf (last visited 1 February 2019). 
Child-friendly justice has specific implications for the way children, in different justice contexts, can be legally empowered to access justice and seek effective remedies.

This paragraph explains the concept of child-friendly justice and its development over the past two decades. Subsequently, it will address some of the key elements of child-friendly justice - i.e. child-friendly information, effective participation and child-friendly outcomes and remedies - in connection with the legal empowerment of children addressed earlier.

\subsection{Concept of Child-friendly Justice}

The concept of child-friendly justice relates directly to the recognition of the child as a rights holder, and is grounded in the case law of the European Court of Human Rights and the General Comments of the CRC Committee (Liefaard, 2016; Liefaard and Kilkelly, 2019). Core rights underlying the concept of childfriendly justice are the child's right to be heard (art.12, CRC) and the right to 'effective participation', which has its legal basis in the right to a fair trial (art. 40, CRC and art. 6, ECHR). The European Court of Human Rights has incorporated the child's right to be heard in its case law under article 8, ECHR on the protection of private and family life and has recognised this right as part of the assessment of the best interests of the child (Kilkelly, 2015; see also, e.g., ECtHR, 3 September 2015, appl. no. 10161/13 (M\& M. v. Croatia)). The right to effective participation was first recognised as an element of the right to a fair trial by the European Court in its ground-breaking judgments T. v. UK and V.v. UK (Kilkelly, 2015: 197: see ECtHR (GC), 16 December 1999, appl. no. 24724/94 (T v. UK); ECtHR (GC), 16 December 1999, appl. no. 24888/94 (V.v. UK)). The European Court ruled that 'it is essential that a child charged with an offence is dealt with in a manner which takes full account of his age, level of maturity and intellectual and emotional capacities, and that steps are taken to promote his ability to understand and participate in the proceedings' (ECtHR (GC), 16 December 1999, appl. no. 24724/94 (Tv. UK), para. 84). This position of the European Court was later endorsed by the CRC Committee on the Rights of the Child (Kilkelly, 2015: 193). In its General Comment No.10 on children's rights in juvenile justice, the CRC Committee observes that " $[\mathrm{a}]$ fair trial requires that the child ... be able to effectively participate in the trial' and that as part of that the child 'needs to comprehend the charges, and possible consequences and penalties, in order to direct the legal representative, to challenge witnesses, to provide an account of events, and to make appropriate decisions about evidence, testimony and the measure(s) to be imposed' (CRC Committee, 2007b, para. 46). The CRC Committee also underscores the significance of acknowledging that juvenile justice proceedings 'should be conducted in an atmosphere of understanding 
to allow the child to participate and to express herself/himself freely (ibid.; Rule 14 Beijing Rules).' The CRC Committee elaborates on this, in relation to the child's right to be heard, by providing that '[a] child cannot be heard effectively where the environment is intimidating, hostile, insensitive or inappropriate for her or his age' (CRC Committee, 2009b: para. 34). Proceedings must be accessible and child-appropriate, which also means that '[p]articular attention needs to be paid to the provision and delivery of child-friendly information, adequate support for self-advocacy, appropriately trained staff, design of court rooms, and clothing of judges and lawyers' (ibid.). The CRC Committee furthermore explains that information is essential for effective participation and exercise of the right to be heard and that court and other hearings should be held in camera. 'Exceptions to this rule should be very limited, clearly outlined in national legislation and guided by the best interests of the child', according to the CRC Committee (CRC Committee, 20ogb: para. 61). The child's right to a fair trial does not require that he should 'understand or be capable of understanding every point of law or evidential detail', but that 'effective participation" in this context presupposes ... a broad understanding of the nature of the trial process and of what is at stake ..., including the significance of any penalty which may be imposed' (ECtHR, 15 June 2004, appl. no. 6o958/oo (S.C. v. $U K)$ : para. 29). The Court also referred to the significance of the right to legal representation in this regard.

The Guidelines on child-friendly justice have embraced the concept of childfriendly justice in relation to all justice proceedings (i.e. beyond the scope of juvenile justice) and provide detailed recommendations, which are relevant for access to justice and, among others, include: information, legal counsel and representation, avoiding undue delay, the environment in and around judicial proceedings (including after disposition) and training of professionals.

\subsection{Meaning of Child-friendly Justice for Access to Justice}

One could identify roughly three elements that ought to be taken into account in making access to justice child-friendly or "child-sensitive": (1) child-friendly information, (2) child participation in proceedings and (3) child-friendly remedies. These elements will successively be addressed in this paragraph.

\subsubsection{Child-friendly information}

Access to information is essential in light of children's access to justice and it is connected to the child's right to information as laid down in art. 17 of the CRC. Child-friendly information means that it should be provided in a manner adapted to the child's age, maturity and specific circumstances. For example, a child in the juvenile justice system requires a different kind of information 
(e.g. on charges, on coercive measures or on the right to a lawyer before and during police interrogations) than a child seeking justice in relation to family law disputes, child protection or asylum procedures (see, e.g., Stalford, Cairns and Marshall, 2017). For children who do not speak the language of the country in which they are, it is essential that information is conveyed in a language they understand (CRC Committee, 2005: paras. 31, $5^{2}$ and 71). Information must also be 'gender and culture sensitive' (UN High Commissioner, 2013: para. 19 with reference to: Joint report, 2012: 7; Guidelines, Part. IV, A: para. 2).

Information available to the child should also be available to 'parents, teachers and people working with and for children' (UN High Commissioner, 2013: para. 20). Children themselves indicate that parents or family members are a main source of information on remedies and that they would prefer and trust their parents in assisting them in accessing justice. In addition, children point out that they prefer receiving information directly, and via school and online channels (ibid.; Kilkelly, 2010; Liefaard and Kilkelly, 2019; see also FRA, 2017). In light of this, the Guidelines on child-friendly justice provide that '[a]s a rule, both the child and parents or legal representative should directly receive the information' and they add that '[p]rovision of the information to the parents should not be an alternative to communicating the information to the child, which underscores that parents can represent their child, but cannot bypass the child's active involvement (Guidelines, Part IV, A, para. 3).

The Guidelines elaborate on the kind of information that should be provided 'promptly and adequately' to children, '[f]rom their first involvement with the justice systems or other competent authorities (such as the police, immigration, educational, social or health care services) and throughout the process.' Child-friendly information contains relevant 'legal information' as well as 'special information services for children such as specialised websites and helplines'. Legal information includes, according to the Guidelines, among other things, information on the rights, systems and procedures in place, possible outcomes and consequences of procedures and possibilities to obtain reparation (see Guidelines, Part IV, A: para. 1).

Information should, thus, include information on rights, including the right to seek remedies to protect and safeguard the enforcement of these rights. Information should also be practical and inform the child about the possible avenues to remedy rights violations and means to find (legal) assistance and additional information where needed. International instruments are rather silent on information regarding the content of legal or other appropriate assistance, while this kind of information can also be regarded relevant, particularly in light of the expectations a child may have regarding the role of his lawyer, for example. 


\subsubsection{Effective Participation in Proceedings}

The second element of child-friendly proceedings revolves around the effective participation of a child in justice proceedings. Participation in an effective and meaningful way is essential for a child's right to access justice (UN High Commissioner, 2013: para. 14). As mentioned earlier, the European Court of Human Rights and the CRC Committee have provided that participation of children requires that one takes full account of their age, maturity, and intellectual and emotional capacities. In addition, steps should be taken to enable children to participate effectively, which means that justice proceedings must be child-appropriate. Key is that a child can express himself 'freely' (art. 12(1) CRC), that the environment in which a child participates is not intimidating or hostile (Guidelines, Part IV, A, para. 11) and that the child is taken seriously in his complaints, grievances and requests. This also means that the child should feel safe and should de facto be protected from reprisals for accessing justice (UN High Commissioner 2013, para. 6o).

In addition, one should bear in mind that child-friendly proceedings also relate to the design of (court) rooms, clothing of actors in that room (formal or informal), the language used (e.g. legal jargon or not) and the information provided to the child. The CRC Committee strongly advocates for hearings in camera as a rule, which should foster the atmosphere of understanding and in addition relates to the protection of the child's and his family's privacy (Guidelines, Part IV, A: para. 6; UN High Commissioner, 2013: para. 48). The specifics of the abovementioned requirements depend on the context in which a child seeks justice. Research on effective participation of children in youth courts across Europe confirms the relevance of the factors mentioned here and recognised in international instruments and case law (Rap, 2013). It adds that one should also invest in the education and training of the professionals involved, including the child's lawyer, and that the involvement of parents contributes to the child's understanding of the proceedings and his effective participation (see further Guidelines, Part IV, D: paras. 54ff). This education and training should also cover communication skills (Guidelines, Part IV, A: paras. 14-15).

The child's right to be heard, underpinning effective participation, is relevant for all children, regardless of their age or maturity. Even though the wording of article 12, CRC leaves room for limiting the right to be heard to those children that are 'capable of forming [their] views', the CRC Committee strongly advocates that this should not be regarded and used as a limitation. It defends the position that, in principle, all children are capable of expressing views, but that the child's age and maturity matters when it comes to the question of how one gives due weight to the views of the child (CRC Committee, 2009b: paras. 28-29; UN High Commissioner, 2013: para. 47). The committee 
recommends not to set age limits (see also Guidelines, Part. IV, D: para. 47). It can be argued that if one agrees that a child has the right to access to justice, this should imply that he can be heard on the matter and that he should be enabled to participate in the proceedings. This does not always mean that the child should be heard directly. Article 12(2), CRC provides that the child's right to be heard means that 'the child shall in particular be provided the opportunity to be heard in any judicial or administrative proceedings affecting the child, either directly, or through a representative or an appropriate body'. The CRC Committee as well as the UN High Commissioner advocate for direct involvement of a child 'wherever possible'. It should be noted, however, that the European Court of Human Rights has made clear that a child does not have a right to be heard directly in court (ECtHR (GC), 8 July 2003, appl. no. 30943/96 (Sahin v. Germany)). It is not clear if the child has such a right in justice proceedings initiated by himself, although it seems defendable.

In any event, the input of children must be given due weight, which implies that the competent authorities clarify and provide feedback to the child on how they have taken the child's input into account and to what extent this has affected their decision (CRC Committee, 20ogb: para. 45. See also UN High Commissioner, 2013: para. 51). The Guidelines on child-friendly justice add that clarification is particularly prompted in case the child's views have not been followed (Guidelines, Part IV, D: para. 49).

This is not to say that one should always listen to a child and children should be (made) aware of that (see also Guidelines, Part IV, D: para. 48), but clarification of the decision is a rather essential component of the child's effective participation. It is strongly related to the effectiveness of the proceedings, the child's sense of (procedural) justice (Rap, 2013) and the accountability of decision makers. However, it can also be regarded relevant as a means to inform the child about his right to appeal the decision (Guidelines, Part IV, E: para. 75 ) ${ }^{15}$ This could mean, for example, that the child receives a written decision on his complaints or grievances in child-friendly wording (ibid.). The importance of oral clarifications directly conveyed to the child should not be underestimated, however. In addition, there is a role to play for the child's legal representative, lawyer or guardian ad litem.

\subsubsection{Child-friendly Outcomes and Remedies}

The final element of child-friendly proceedings concerns the outcomes and ultimately the remedies provided. As just mentioned, the effective participation

15 It should be noted that children may not always have the right to appeal the decision, e.g. in case he is not considered a party to the proceedings. 
of a child affects the effectiveness of the remedies, which also relates the child's sense of (procedural) justice (see, e.g., Tyler, 2006; see also Rap, 2013) and the accountability of perpetrators. But what about child-friendly remedies? What should they entail? International law and children's rights standards do not provide much guidance here. It can be argued that remedies for children can have different forms and that the pedagogical orientation of many legal systems in relation to children provides room for much creativity in this regard. An example of such an orientation can be found in the case law of the Dutch Council for the Administration of Criminal Justice and Child Protection (i.e. the appellate court in complaints procedures for children in youth custodial institutions in the Netherlands). The Appeals Committee of the Council has found that the compensation must fit the nature and content of the challenged decision and that three elements should be taken into account. First, the compensation should be of pedagogical significance; secondly, it should preferably be non-financial compensation; and thirdly, it should meet the wishes of the child concerned (see Appeals Committee, 19 November 2003, 03/1608/JA; see further Liefaard, 2008:531-532). The third element means that the child should be heard when defining the compensation, which connects well to article 12 of the CRC.

The Guidelines, furthermore, underscore the importance of timely enforcement of decisions concerning remedies. 'National authorities should take all necessary steps to facilitate the execution of judicial decisions/rulings involving and affecting children without delay' (Guidelines, Part IV, E, para. 76). And when a decision has not been enforced, the child should be informed and granted access to justice (ibid., para. 77). Overall this part of child-sensitive access to justice mechanisms is the least explored, legally, practically and academically.

\section{6 \\ Concluding Observations - Towards a Specific Implementation and Research Agenda}

This contribution has made clear that children have a right to access justice under international human rights law, with corresponding obligations for states. Children experience specific challenges in enjoying their right to access justice and seek effective remedies against (alleged) violations of their human rights and fundamental freedoms. These challenges relate to children's specific, dependent and vulnerable status, but also to the lack of willingness to accept that children have rights, that these rights must be enforced and that children must be enabled to exercise their rights, which includes their right to access justice and seek effective remedies. 
Although the concept of access to justice is not new at all, it has taken a while before children were regarded as bearers of the right to an effective remedy and access to justice. Consequently, the field of access to justice for children is relatively young. And even though it has gradually received more attention and can count on even more attention since the adoption of the Third Optional Protocol to the CRC, one must acknowledge that for an effective implementation of access justice for children, one needs to move beyond the level of standard-setting. There is a role to play for the CRC Committee (and more broadly for the international community), as well as for both state and non-state actors in developing an implementation agenda targeted at the implementation of access to justice for children in specific contexts. Until now, international developments on this matter have resulted in comprehensive but also rather generic documents providing standards and/or guidance for states. And even though all these documents acknowledge that access to justice has many different faces and requires specific action towards specific groups of children in specific contexts, they are not (yet) offering much guidance on specific approaches. Fortunately, a number of csos as well as UNICEF have stepped in and developed specific projects on access to justice (see, e.g., UNICEF, 2015, ECPAT International, 2017, and ACPF, 2018). These projects are not consistent, however, in the way that they approach access to justice as a concept. Moreover, projects in this field seem rather fragmented and their added value is not rigorously measured and evaluated.

This contribution concludes with the submission that there is a world to win if academia steps in as well, joins forces with the stakeholders mentioned and contributes to the development of (the concept of) access to justice, as a fundamental human right of every child. It could assist in conceptualising access to justice and assess and scrutinise the requirements for an effective implementation, particularly in relation to: (1) specific groups of children, including the most vulnerable and stigmatised groups of children, (2) specific contexts, including family law disputes, child protection measures, juvenile justice proceedings, migration and asylum proceedings, deprivation of liberty, biomedical issues, issues related to violence against and exploitation of children and matters related to responsibilities of businesses for children's rights, and (3) specific forms of access to justice, including formal justice proceedings, alternative forms of dispute resolution, informal ways of providing for remedies, collective complaint mechanisms and other means, at the national and international level, to address gross or systematic violations of children's rights. Academic research could also contribute to a better understanding of access to justice and assist in further developing the requirements for effective enjoyment of children's access to justice, again in ways adapted to children's 
age and maturity. And finally, it could also help to reflect critically on the added value of access to justice as an individual child's right in light of his specific characteristics, revolving around development, vulnerability, autonomy, agency and special relationship with parents and the extended family. There is no doubt that access to justice can be of added value for children. Its true meaning, however, can only be assessed as part of a joint effort, which comprehensively scrutinises the concept and its practical implications for children around the world. It needs no explanation that children themselves should be part of this on-going exercise as well.

\section{Acknowledgement}

The author would like to thank Ms. Chris Sandelowsky, LL.M for her assistance. This article is an amended version of the Preliminary report (preadvies), "Access to Justice for Children" prepared for the Royal Netherlands Society of International Law (KNVIR) in 2017 (Liefaard 2017b). The author is grateful for the research assistance and contributions of Ms. Daniella Zlotnik, LL.M and for the feedback on draft versions of this report from Prof. Dr Jaap E. Doek, Prof. Dr Julia J. Sloth-Nielsen and Dr Stephanie E. Rap.

\section{References}

ACPF, Spotlighting the Invisible: Justice for children in Africa (Addis Ababa: African Child Policy Forum, 2018).

Arts, K., "Twenty-Five Years of the United Nations Convention on the Rights of the Child: Achievements and Challenges", NILR 2014 (61(3)), 267-303. DOI:10.1017/ So165070X14001272.

Bedner, A. and Vel, J.A.C., "An analytical framework for empirical research on Access to Justice", Law, Social Justice \& Global Development Journal 2010 (1): http:// www2.warwick.ac.uk/fac/soc/law/elj/lgd/2010_1/bedner_vel (last visited, 1 February 2019).

Boezaart, T., "Child Law, the Child and South African Private Law" in: T. Boezaart (ed.), Child Law in South Africa (Claremont: Juta \& Co. Ltd, 2009, 3-37).

Buss, E., "You're my what? The Problem of Children's Misperceptions of Their Lawyer's Roles", Fordham Law Review 1996 (64), 1699-1762.

Carter, E.I., Access to justice for children with disabilities: The South African context (unpublished LLD Thesis, University of Pretoria, 2016). 
Clark, S., "Child Rights and the Movement From Status to Agency: Human Rights and the Removal of the Legal Disabilities of Vulnerability", Nordic Journal of International Law 2015 (84(2)), 183-220. Dor: 10.1163/15718107-08402003.

Coley, M., "Children's Voices in Access and Custody Decisions: the Need to Reconceptualize Rights and Effect Transformative Change", Appeal Rev. Current L. \& L. Reform 2007 (12), 48-72.

CRC Committee 2007a, UN Committee on the Rights of the Child, General Comment No. 8 (2006): The right of the child to protection from corporal punishment and other cruel or degrading forms of punishment (arts. 19; 28, para. 2; and 37, inter alia), CRC/C/GC/8, 2 March 2007.

CRC Committee 2007b, UN Committee on the Rights of the Child, General Comment No. 10 (2007): Children's Rights in Juvenile Justice, CRC/C/GC/10, 25 April 2007.

CRC Committee 2009a, UN Committee on the Rights of the Child, General Comment

No. 11 (2009): Indigenous children and their rights under the Convention, CRC/C/ GC/11, 12 February 2012.

CRC Committee 2009b: UN Committee on the Rights of the Child, General Comment No. 12 (2009): The right of the child to be heard, CRC/C/GC/12, 20 July 2009.

CRC Committee 2011: UN Committee on the Rights of the Child, General Comment No. 13 (2011): The right of the child to freedom from all forms of violence, $\mathrm{CRC} / \mathrm{C} / \mathrm{GC} / 13,18$ April 2011.

CRC Committee 2013a: UN Committee on the Rights of the Child, General Comment No. 16 (2013) on State obligations regarding the impact of the business sector on children's rights, CRC/C/GC/16, 17 April 2013.

CRC Committee 2013b: UN Committee on the Rights of the Child, General Comment No. 15 (2013) on the right of the child to the enjoyment of the highest attainable standard of health (art. 24), CRC/C/GC/15, 17 April 2013.

CRIN, Rights, Remedies \& Representation. Global Report on Access to Justice for Children, Child Rights Information Network, 2016.

Duquette, D.N. and Darwall, J., "Child Representation in America: Progress Report from the National Quality Improvement Center”, Family Law Quarterly 2012 (46(1)), $87-138$.

ECPAT International, Through the Eyes of the Child: Barriers to Access to Justice and Remedies for Child Victims of Sexual Exploitation (Bangkok: ECPAT International, 2017).

Elrod, L.D., "Raising the Bar for Lawyers Who Represent Children: aba Standards of Practice for Custody Cases", Family Law Quarterly 2003 (37(2)), 105-129.

European Union Agency for Fundamental Rights, Perspectives and experiences of children involved in judicial proceedings as victims, witnesses or parties in nine EUMember States (Luxembourg: Publications Office of the European Union, 2017). 
European Union Agency for Fundamental Rights and the Council of Europe, Handbook on European law relating to the rights of the child (Luxembourg: Publications Office of the European Union, 2015).

European Union Agency for Fundamental Rights and the Council of Europe, Handbook on European law relating to access to justice (Luxembourg: Publications Office of the European Union, 2016).

Feria Tinta, M., "The CRC as a Litigation Tool Before the Inter-American System of Protection of Human Rights", Chapter DoI: 10.1007/978-94-017-9445-9_14 in T. Liefaard and J.E. Doek (eds.), Litigating the Rights of the Child. The UNConvention on the Rights of the Child in Domestic and International Jurisprudence (Dordrecht: Springer, 2015, 231-248). Book DOI: 10.1007/978-94-017-9445-9.

Fortin, J., Children's Rights and the Developing Law (Cambridge: Cambridge University Press, 2009, 234).

Francioni, F., "The Rights of Access to Justice under Customary International Law" in F. Francioni (ed.), Access to Justice as a Human Right (Oxford: Oxford University Press, 2007, 1-55). DOI:10.1093/acprof:oso/9780199233083.003.0001.

Fridriksdottir, H., "Relational Representation: The Empowerment of Children in Justice Systems", Chapter DoI: 10.1163/9789004297432_oo8, in S. Mahmoudi, P. Leviner, A. Kaldal and K. Lainpelto (eds.), Child-Friendly Justice: A Quarter of a Century of the UN Convention on the Rights of the Child (Leiden: Brill | Nijhoff, 2015, 55-72). Book DoI: 10.1163/9789004297432.

Inter-American Commission on Human Rights (IACHR), Access to Justice as a Guarantee of Economic, Social and Cultural Rights. A Review of the Standards Adopted by the Inter-American System of Human Rights, 7 September 2007, OEA/Ser.L/V/ II.129.

Joint report of the Special Representative of the Secretary-General on Violence against Children and the Special Rapporteur on the Sale of Children, Child Prostitution and Child Pornography on Safe and child-sensitive counselling, complaint and reporting mechanisms to address violence against children, New York, 2012.

Kennan, N. and Kilkelly, U., Children's involvement in criminal, civil and administrative judicial proceedings in the 28 Member States of the EU. Policy Brief (Luxembourg: Publications Office of the European Union, 2015).

Kilkelly, U., Listening to children about justice: report of the council of Europe; consultation with children on child-friendly justice (Strasbourg: 2010).

Kilkelly, U., "The CRC in Litigation Under the ECHR", Chapter DOI: 10.1007/978-94-0179445-9_12, in T. Liefaard and J.E. Doek (eds.), Litigating the rights of the child: the UN Convention on the Rights of the Child in domestic and international jurisprudence (Dordrecht: Springer, 2015, 193-209). Book DoI: 10.1007/978-94-017-9445-9.

Kilkelly, U. and Liefaard, T. (eds.), International Human Rights of Children (Singapore: Springer, 2019). 
Liefaard, T., Deprivation of Liberty of Children in Light of International Human Rights Law and Standards (Diss. Amsterdam, VU University, Antwerp/Oxford/Portland: Intersentia Publishing, 2008).

Liefaard, T., "Juvenile justice from a children's rights perspective" in W. Vandenhole, E. Desmet, D. Reynaert and S. Lembrechts (eds.), Routledge International Handbook of Children's Rights Studies (New York: Routledge, 2015, 234-256).

Liefaard, T., "Child-friendly justice. Protection and participation of children in the justice system", Temple Law Review 2016 (88(4)), 905-927.

Liefaard, T., "Access to Justice for Children Deprived of Their Liberty in Center for Human Rights and Humanitarian Law", Anti-Torture Initiative (eds.), Protection Children Against Torture in Detention. Global Solutions for a Global Problem (Washington D.C: American University, Washington College of Law, 2017a, 57-80).

Liefaard, T., "Access to Justice for Children" in Koninklijke Nederlandse Vereniging voor Internationaal Recht (Royal Netherlands Society of International Law), Protecting the Rights of Families and Children in a Changing World, (Preadviezen Mededelingen No. 144) (The Hague: T.M.C. Asser Press, 2017b, 35-88).

Liefaard, T. and Doek, J.E., Litigating the Rights of the Child. The UN Convention on the Rights of the Child in Domestic and International Jurisprudence (Dordrecht: Springer Science+Business Media, 2015, 1-12). DoI: 10.1007/978-94-017-9445-9.

Liefaard, T. and Kilkelly, U., "Child-Friendly justice: past, present and future" in B. Goldson (ed.), Juvenile Justice in Europe: Past, Present and Future (Abingdon/New York: Routledge, 2019, 57-73).

Liefaard, T. and Sloth-Nielsen, J.J. (eds.), The United Nations Convention on the Rights of the Child. Taking Stock after 25 Years and Looking Ahead (Leiden: Brill|Nijhoff, 2017). Book DOI: 10.1163/9789004295056.

Nolan, A., Children's Socio-Economic Rights, Democracy and the Courts (Oxford: Hart Publishing, 2011).

O'Donnell, D., The Right of Children to be heard: Children's right to have their views taken into account and to participate in legal and administrative proceedings (UNICEF: Innocenti Research Centre, 2009).

Parkes, A., Children and International Human Rights Law. The Right of the Child to be Heard (London/New York: Routledge, 2013).

Quennerstedt, A., "Children, But Not Really Humans? Critical Reflections on the Hampering Effect of the ' 3 p's', International Journal of Children's Rights 2010 (18(4)), 619-635. DOI: $10.1163 / 157181810 X 490384$.

Rap, S.E., The Participation of Juvenile Defendants in the Youth Court (Diss. Utrecht, Amsterdam: Pallas Publications, 2013).

Rees, O., "Dealing with Individual Cases: An Essential Role for National Human Rights Institutions for Children?", International Journal of Children's Rights 2010 (18(3)), 417-436. DOI: $10.1163 / 157181810 X 495866$. 
Ruggiero, R., "Ombudspersons for children in selected decentralised European States: implementing the CRC in Belgium, Spain and the United Kingdom", Interdisciplinary Journal of Family Studies 2013 (18(2)), 65-97.

De Schutter, O., International Human Rights Law. Cases, Materials, Commentary (Cambridge: Cambridge University Press, 2010).

Shelton, D., Remedies in international human rights law (Oxford: Oxford University Press, 2015). Dor:10.1093/acprof:oso/9780199207534.001.0001.

Skelton, A., "South Africa”, Chapter DoI: 10.1007/978-94-017-9445-9_2 in T. Liefaard and J.E. Doek (eds.), Litigating the Rights of the Child. The UN Convention on the Rights of the Child in Domestic and International Jurisprudence (Dordrecht: Springer, 2015, 13-30). Book DoI: 10.1007/978-94-017-9445-9.

Skelton, A., "Complaints and Remedies" in U. Kilkelly and T. Liefaard (eds.), International Human Rights of Children (Singapore: Springer, 2018, 1-27). DoI: 10.1007/978-981-10-3182-3_3-1.

Sloth-Nielsen, J.J., “Children's Rights Litigation in the African Region: Lessons from the Communications procedure under the ACRWC", Chapter DOI: 10.1007/978-94-0179445-9_15 in T. Liefaard and J.E. Doek (eds.), Litigating the Rights of the Child. The UNConvention on the Rights of the Child in Domestic and International Jurisprudence (Dordrecht: Springer, 2015, 249-265). Book Dor: 10.1007/978-94-017-9445-9.

Stalford, H., Cairns, L., Marshall, J., “Achieving Child Friendly Justice through Child Friendly Methods: Let's Start with the Right to Information", Social Inclusion 2017, 3, 207-218. DOI: 10.17645/si.v5i3.1043.

Tyler, T.R., Why people obey the law (Princeton/Oxford: Princeton University Press, 2006).

UN Committee on the Rights of the Child, General Comment No. 2 (2002): The Role of Independent National Human Rights Institutions in the Promotion and Protection of the Rights of the Child, CRC/GC/2002/2, 15 November 2002.

UN Committee on the Rights of the Child, General Comment No. 5 (2003): General measures of implementation of the Convention on the Rights of the Child, $\mathrm{CRC} / \mathrm{GC} / 2003 / 5$, 27 November 2003.

UN Committee on the Rights of the Child, General Comment No. 6 (2005): Treatment of Unaccompanied and Separated Children Outside their Country of Origin, CRC/ GC/2005/6, 1 September 2005 .

UN Human Rights Committee, General Comment No. $3^{1}$ [80], The nature of the general legal obligation imposed on States Parties to the Covenant, 26 May 2004, CCPR/C/21/ Rev.1/Add.13.

UN Human Rights Council, Access to justice for children. Report of the United Nations High Commissioner for Human Rights, UN Doc. A/HRC/25/35.

UN Secretary-General (UNSG), Guidance Note of the Secretary-General: UN Approach to Justice for Children, September 2008. 
UNDP, Access toJustice: Practice Note, 9 March 2004.

UNDP, Programming for Justice: Access for All. A Practitioner's Guide to a Human RightsBased Approach to Access to Justice, Bangkok: United Nations Development Programme 2005 .

UNICEF, UN Common Approach to Justice for Children, March 2008, https://www .un.org/ruleoflaw/blog/document/un-common-approach-to-justice-for-children/ (last visited, 1 February 2019).

UNICEF, UN Global Compact \& Save the Children, Children's Rights and Business Principles, June 2010, https://www.unicef.org/csr/css/PRINCIPLES_23_02_12_FINAL_ FOR_PRINTER.pdf (last visited, 1 February 2019).

UNICEF, Championing Children's Rights. A global study of independent human rights institutions for children, Florence: UNICE F Office of Research-Innocenti 2013. UNICEF, Children's Equitable Access to Justice, Central and Eastern Europe and Central Asia, Geneva: UNICEF 2015. 